\title{
Semen quality in workers exposed to 2-ethoxyethanol
}

\author{
JENNIFER M RATCLIFFE,' S M SCHRADER, ${ }^{2}$ D E CLAPP,' W E HALPERIN,' \\ T W TURNER, ${ }^{2}$ R W HORNUNG ${ }^{3}$
}

\begin{abstract}
From the Industrywide Studies Branch,' Division of Surveillance, Hazard Evaluations and Field Studies, Experimental Toxicology Branch, ${ }^{2}$ Division of Biomedical and Behavioural Science, and Support Services Branch, ${ }^{3}$ Division of Surveillance, Hazard Evaluations and Field Studies, National Institute for Occupational Safety and Health, Cincinnati, Ohio 45226, USA
\end{abstract}

\begin{abstract}
To evaluate whether long term exposure to 2-ethoxyethanol (2EE) may affect semen quality, a cross sectional study was conducted among men exposed to 2EE used as a binder slurry in a metal castings process. Full shift breathing zone exposures to 2EE ranged from non-detectable to 24 ppm (geometric mean 6.6 ppm). Because of the potential for substantial absorption of 2EE through skin exposure, urine measurements of the metabolite of 2EE, 2-ethoxyacetic acid (2EAA) were conducted, showing levels of 2EAA ranging from non-detectable to $163 \mathrm{mg} 2 \mathrm{EAA} / \mathrm{g}$ creatinine. Only 37 exposed men ( $50 \%$ participation) and 39 non-exposed comparison ( $26 \%$ participation) from elsewhere in the plant provided a sperm sample. A questionnaire to determine personal habits, and medical and work histories, and a physical examination of the urogenital tract were also administered. The average sperm count per ejaculate among the workers exposed to 2EE was significantly lower than that of the unexposed group (113 v 154 million sperm per ejaculate respectively; $p=0.05$ ) after consideration of abstinence, sample age, subjects' age, tobacco, alcohol and caffeine use, urogenital disorders, fever, and other illnesses. The mean sperm concentrations of the exposed and unexposed groups did not significantly differ from each other ( 44 and $53 \mathrm{million} / \mathrm{ml}$ respectively). No effect of exposure to $2 \mathrm{EE}$ on semen volume, sperm viability, motility, velocity, and normal morphology or testicular volume was detected, although some differences in the proportion of abnormal sperm shapes were observed. These data suggest that there may be an effect of 2EE on sperm count among these workers, although the possibility that other factors may be affecting the semen quality in both exposed and unexposed men in this population or that the results reflect bias introduced by the low participation rates cannot be excluded.
\end{abstract}

2-Ethoxyethanol (2EE; ethylene glycol monoethyl ether) is one of a family of glycol ethers used in a wide variety of industries as solvents, thinners, anti-icing additives, and other products. ${ }^{1}$ The National Institute for Occupational Safety and Health (NIOSH) has estimated that at least 400000 workers are potentially exposed to 2EE in the United States. ${ }^{2}$ The current Occupational Safety and Health Administration (OSHA) eight hour time weighted average (TWA) permissible exposure limit (PEL) for 2EE is $200 \mathrm{ppm}^{3}$; this is based primarily on the renal, hepatic, and haematological effects of 2EE observed in early animal experiments.' The American Conference of Governmental Industries Hygienists (ACGIH) recommends a threshold limit value (TLV) of 5 ppm as an eight hour TWA. ${ }^{4}$ Both the OSHA PEL and the ACGIH TLV bear the "skin" notation indicating the potential for absorption of toxic amounts of 2EE through the intact skin. On the basis of recent animal data on the adverse

Accepted 8 June 1988 reproductive effects of $2 E E$ in both female and male animals, NIOSH has recommended that exposure be reduced to the lowest extent feasible. ${ }^{1}$ 2EE has also been reported to increase the rate of chromosome aberrations and sister chromatid exchanges in Chinese hamster ova in vitro, ${ }^{5}$ but has not been shown to be mutagenic in the Ames test, according to a recent review by McGregor. ${ }^{6}$ Currently, there are no data available on the potential carcinogenicity of $2 \mathrm{EE}$ in animals or man.

With respect to the male reproductive toxicity of 2EE, testicular atrophy and microscopic testicular changes (including degeneration of seminiferous tubules and damage to dividing spermatocytes and spermatids) have been reported in rats given $2 \mathrm{EE}$ by mouth $^{7-10}$ or subcutaneously ${ }^{8}$ at various doses, in mice $^{11}$ and $\operatorname{dogs}^{8}$ after oral administration, and in rabbits after exposure by inhalation. ${ }^{12}$ Oudiz et al found partially reversible severe oligozoospermia or azoospermia among rats seven weeks after dosing with 1872 and $2808 \mathrm{mg} / \mathrm{kg} 2 \mathrm{EE}$ for five days, and a 
significant increase in abnormal sperm morphology after treatment with $936 \mathrm{mg} / \mathrm{kg} 2 \mathrm{EE} .{ }^{13}$ Finally, Lamb $e t$ al found dose related decreases in sperm motility, an increase in the percentage of morphologically abnormal sperm, and decreases in testicular weight in mice given $1-2 \% 2 E E$ in their drinking water for 14 weeks. ${ }^{14}$ A significant reduction in fertility (number of live pups per litter) among untreated females mated with the males treated with $2 \% 2 \mathrm{EE}$ was also observed. There are no previous studies of the reproductive effects of $2 \mathrm{EE}$ in man.

Owing to concern regarding the possible reproductive hazards to male workers of exposure to 2EE in a slurry mix used to prepare ceramic shells for casting metal parts, NIOSH researchers conducted an industrial hygiene survey and a cross sectional semen study at a metal casting plant in Portland, Oregon. ${ }^{\text {is }}$ The present paper describes the findings from the semen study and presents a summary of the industrial hygiene surveys; the latter are described in detail elsewhere. ${ }^{16}$

\section{Materials and methods}

\section{DESCRIPTION OF PROCESS AND WORKFORCE}

The metal castings company is engaged in the manufacture of precision cast parts, ranging from compressors and turbochargers for aircraft to prosthetic limb joints, using the "lost wax" method of investment casting. Wax replicas of parts are repeatedly immersed in a slurry composed principally of ethanol and 2EE and dipped in a sand shower to build up a ceramic shell mould from which the wax is melted out and molten metal poured in for casting. Shells are dried on belts and racks in the investing rooms; the recirculation of air disperses vaporising 2EE evenly throughout these areas.

About 80 male workers are employed in the investing departments in three separate buildings at the plant; these include men who make up or who periodically check the slurry mix ("utility investors"), or both; hand dippers and grabber operators who dip the wax moulds in the slurry and sand; shell processors who handle the finished shells; supervisors; and engineers who regularly enter the investing rooms. All are potentially exposed to airborne levels of $2 \mathrm{EE}$ by inhalation. Airborne 2EE vapour may also be absorbed through the skin and some workers have potential skin exposure from splashes and spills of slurry. Some workers wore gloves but no other personal protective equipment or respirators were used at the time of our survey.

EXPOSURE MEASUREMENTS

Two industrial hygiene surveys were conducted, one about two months before and the second during the semen study. Air samples were collected and analyse for 2EE by gas chromatography according to NIOSH: method $1403 .{ }^{17}$ Full shift breathing zone samples were obtained from workers in each job category in the investing departments in each building on at least twळ separate days. No short term samples were taken sinces there were no identifiable sources of peak exposures $\Phi$ Area samples were also obtained at a higher flow rate than the personal samples, thereby permitting a lower? limit of detection in the event that airborne levels were below $0 \cdot 1 \mathrm{ppm}$. Blank and spiked field samples were analysed (blind) to check for contamination an analyte recovery rate.

To monitor urine excretion of the metabolite o $B$ 2EE, 2-ethoxyacetic acid (2EAA), 24 hour and spos urine samples were obtained from randomly selecteos volunteers in $200 \mathrm{ml}$ plastic vials, transferred to $20 \mathrm{~m} \psi$ scintillation vials, and frozen for shipment to thee laboratory. Samples were analysed by the method of Smallwood et al. ${ }^{18}$ Blood samples were also obtainedfrom nine exposed and four unexposed workers te determine whether the parent compound, 2EE, could be detected in blood as shown in animals, ${ }^{18}$ but not previously in man. Five millilitres samples wereु obtained at the end of a shift, chilled, and analysed as described by Smallwood et al..$^{18}$ Five spiked samples containing $25 \mu \mathrm{g} 2 \mathrm{EE} / \mathrm{g}$ showed $100 \%$ recovery suggesting that the method was adequate. None of the samples obtained contained detectable levels of $2 \mathrm{EEO}$ These limited data suggest that, if 2EE is present in the blood, it is at a level below the detection limit of $10 \mu \mathrm{g} / \mathrm{g}$ blood.

\section{SELECTION OF PARTICIPANTS}

In cooperation with the plants' industrial hygienist, $\mathrm{a} \mid \mathrm{\Phi}$ male workers who could be potentially exposed to 2EE (on a daily basis) were identified from personnel listso Each man (a total of 79 available at the time of the study) was interviewed confidentially to describe the purpose and procedures of the study and to solici俑 participation. Six workers were ineligible owing to vasectomies or employment in a potentially exposed job category for less than one month. Fifty men (68\% of the 73 eligible men) agreed to participate, of whon 37 provided semen samples ( $50 \%$ of the eligible men)

Randomly selected workers from elsewhere in the plants, including workers in the wax mould preparation and metal casting departments, $x$ ray and finishing departments, quality controllers, and proces engineers, were interviewed to solicit participation Fifty of about 150 unexposed men who were interviewed agreed to participate, of whom $39.26 \%$ ) provided semen samples. Men who had previouslo worked in the investing department (with previous potential exposure to $2 \mathrm{EE}$ ) were excluded. 
QUESTIONNAIRE, PHYSICAL EXAMINATION, AND SEMEN COLLECTION

Each participant was given a questionnaire by personal interview to provide data on demographic characteristics, personal habits (including tobacco, alcohol, and caffeine consumption), medical history, work history, and history of current and previous exposures to chemical and physical hazards. Participants underwent a brief physical examination concentrating on the urogenital tract. Testicular volume was measured using a Prader orchidometer. Subjects were asked to provide a semen specimen at home by masturbation into the glass jar provided, after a minimum of two days of sexual abstinence, and to bring the sample in the thermos provided to the medical department within an hour of collection, as described previously. ${ }^{19}$

\section{SEMEN ANALYSIS METHODS}

Semen analysis methods are described in detail elsewhere,$^{20}$ but are briefly outlined below. The methods of analysis for semen $\mathrm{pH}$ and volume, sperm concentration, viability, motility, velocity, morphology, and morphometry have been described in detail previously. ${ }^{19}$ Sperm viability was measured by stain exclusion, modified from Eliasson and Treichl, ${ }^{21}$ and by hyposomotic swelling according to Jeyendran et $a .^{22}$ Sperm motility and velocity were measured using videotapes and an image analysis system; both actual path and straight line ("distance") velocity were recorded. ${ }^{22-25}$ Sperm morphology was scored according to Zanefield and Polakoski ${ }^{26}$ and morphometric analysis of sperm head shapes analysed from air dried slides as described in Schrader et al..$^{27}$ Video recordings of samples, viability assessments, sperm counts, volume and $\mathrm{pH}$ measurements, and preparation of air dried smears were conducted on fresh samples at the field site. Analysis of video tapes for motility and velocity measurements and morphological analysis of slides were conducted in the laboratory. All samples were processed and analysed in blind fashion by the investigators.

\section{STATISTICAL ANALYSIS}

Data for each semen characteristic were analysed as described previously. ${ }^{19}$ Transformations were performed for data that were not normally distributed after testing for normality using the Shapiro-Wilks statistic $^{28}$; for proportions-for example, the percentage of motile sperm-logistic transformations were used, and a square root transformation was found to approximate most closely to a normal distribution for sperm concentration and count per ejaculate. Data for other characteristics did not significantly depart from normal. Variables were analysed using two sided $t$ tests and least squares stepwise linear regression analysis. In the case of abnormal sperm morphology classifications data were analysed using the CATMOD (formerly FUNCAT) procedure $^{29}$ which permits multivariate modelling of categorical frequency data by performing a simultaneous analysis of the frequency of responses in each category of abnormal sperm (by comparison with the proportion of normal sperm) in relation to exposure and other independent variables. Approximate $\chi^{2}$ statistics are produced. Tobacco smoking (cigarettes, pipes, cigars a day), alcohol consumption (drinks a week), caffeine consumption (cups of coffee or tea, or both, a day), prescription medication use in the past year, history of fever within the past three months, history of urogenital disorders or an abnormal urogenital examination (including the presence of varicocele) and prior exposure history, the subject's age, sample age at analysis, and sexual abstinence time were considered a priori for inclusion in regression models as potential confounders. Variables were excluded from the model if the $p$ value of the coefficient was less than 0.1 and the variable had a negligible effect on the exposure variable.

\section{Results}

\section{EXTENT OF EXPOSURE}

Air samples

Full shift TWA area air samples collected in survey I, about two months before the semen study (survey II),

Table $12 E E$ exposure by job category and location (8 hour TWA breathing zone and area samples; parts per million*)

\begin{tabular}{|c|c|c|c|c|}
\hline Job category/location & $\begin{array}{l}\text { Survey It } \\
\text { gm gsd }\end{array}$ & No & $\begin{array}{l}\text { Survey II } \\
\text { gm gsd }\end{array}$ & No \\
\hline \multicolumn{5}{|l|}{ Building A: } \\
\hline $\begin{array}{l}\text { Investment room } \\
\text { 2EE mixing room }\end{array}$ & $\begin{array}{r}16 \cdot 9(1 \cdot 1) \\
4 \cdot 8(2 \cdot 0)\end{array}$ & {$[3]$} & $\begin{array}{l}3.0(6 \cdot 8) \\
\text { NA }\end{array}$ & [3] \\
\hline \multicolumn{5}{|l|}{ Breathing zone samples: } \\
\hline $\begin{array}{l}\text { Hand dipper } \\
\text { Hand shell processor } \\
\text { Utility investor }\end{array}$ & $\begin{array}{r}14 \cdot 5(1 \cdot 2) \\
3 \cdot 0(4 \cdot 7) \\
8 \cdot 5(1 \cdot 6)\end{array}$ & $\begin{array}{l}{[5]} \\
{[3]} \\
{[3]}\end{array}$ & $\begin{array}{l}\text { NA } \\
\text { NA } \\
\text { NA }\end{array}$ & \\
\hline \multicolumn{5}{|l|}{ Building B: } \\
\hline \multicolumn{5}{|l|}{ Area samples: } \\
\hline $\begin{array}{l}\text { Investment room } \\
2 \mathrm{EE} \text { mixing room }\end{array}$ & $\begin{array}{r}10 \cdot 7(1 \cdot 3) \\
6 \cdot 6(1 \cdot 4)\end{array}$ & {$[3]$} & $\begin{array}{l}14 \cdot 9(1 \cdot 1) \\
\text { NA }\end{array}$ & [4] \\
\hline \multicolumn{5}{|l|}{ Breathing zone samples: } \\
\hline $\begin{array}{l}\text { Grabber operator } \\
\text { Forklift shell processor } \\
\text { Supervisor }\end{array}$ & $\begin{array}{l}6 \cdot 5(1 \cdot 1) \\
\text { NA } \\
6 \cdot 0(1 \cdot 1)\end{array}$ & [2] & $\begin{array}{c}10 \cdot 0(2 \cdot 9) \\
8 \cdot 5(2 \cdot 4) \\
5 \cdot 0(1 \cdot 1)\end{array}$ & [7] \\
\hline \multirow{2}{*}{\multicolumn{5}{|c|}{ Building C: }} \\
\hline \multicolumn{3}{|l|}{ Area samples: } & & \\
\hline $\begin{array}{c}\text { Investment room (A) } \\
\text { Breathing zone samples: }\end{array}$ & NA & & $2 \cdot 4(5 \cdot 5)$ & [5] \\
\hline $\begin{array}{l}\text { Grabber operator } \\
\text { Forklift shell processor }\end{array}$ & $\begin{array}{l}\text { NA } \\
\text { NA }\end{array}$ & & $\begin{array}{l}5 \cdot 7(2 \cdot 5) \\
1 \cdot 6(2 \cdot 2)\end{array}$ & [2] \\
\hline
\end{tabular}

*Limit of detection for 2EE is $0.03 \mathrm{ppm}$ (area samples) and 0.15 ppm (breathing zone samples).

† Survey I conducted two months before semen study; survey II conducted during the semen study. 2EE use discontinued in buildings $A$ and $C$ at the time of survey II.

$\mathrm{gm}=$ Geometric mean.

gsd $=$ Geometric standard deviation

No $=$ Number of samples.

NA $=$ Not applicable or not sampled. 
Table 2 Urine excretion of $2 E A A$ ( $m g$ $2 E A A / g$ creatinine*) by job category

\begin{tabular}{llll}
\hline Job category & Mean & $S D$ & No \\
\hline Hand dipper & $35 \cdot 5$ & $(10 \cdot 9)$ & 10 \\
Grabber operator & 84.9 & $(31 \cdot 3)$ & 16 \\
Shell processor & $73 \cdot 0$ & $(11 \cdot 9)$ & 5 \\
Shell processor & ND & & 1 \\
$\quad$ (2 days off work) & 29.9 & $(6.4)$ & 5 \\
Supervisor & $17 \cdot 3$ & $(2 \cdot 3)$ & 3 \\
Supervisor & ND & & 9 \\
$\quad$ (1 day off work) & & & \\
\hline
\end{tabular}

No $=$ Number of individual urine voids.

*Limit of quantitation $=10 \mathrm{mg} / \mathrm{l}$ (before creatinine adjustment).

indicated levels of $2 \mathrm{EE}$ ranging from $4.8 \mathrm{ppm}$ to 16.9 ppm (geometric mean $6.5 \mathrm{ppm}$ ) at two of the three buildings ( $A$ and $B$ ) (table 1). Exposures in the investing room in both buildings were generally higher than chemical storage and mixing areas. About two to three weeks before survey II, the use of $2 \mathrm{EE}$ was suspended in buildings $A$ and $C$; although some 2EE was still in the process stream, the concentrations in building $\mathbf{A}$ (and presumably in building $\mathbf{C}$ ) appeared to have declined on average in survey II (table 1). In building B, where the use of $2 \mathrm{EE}$ was not discontinued,

Table 3 Characteristics of unexposed and exposed workers

\begin{tabular}{|c|c|c|}
\hline & $\begin{array}{l}\text { Unexposed } \\
(n=38)\end{array}$ & $\begin{array}{l}\text { Exposed } \\
(n=37)\end{array}$ \\
\hline $\begin{array}{l}\text { Duration of employment }(y) \\
\text { (mean } \pm S D)\end{array}$ & $5 \cdot 2 \pm 5 \cdot 0$ & $7 \cdot 3 \pm 5 \cdot 5$ \\
\hline $\begin{array}{l}\text { Duration of employment in } 2 E E \\
\text { exposed jobs }(y)(\text { mean } \pm S D)\end{array}$ & - & $4 \cdot 9 \pm 4 \cdot 1$ \\
\hline $\begin{array}{l}\text { Age of subject } \\
\text { (mean } \pm \text { SD) }\end{array}$ & $30 \cdot 3 \pm 7 \cdot 5$ & $30 \cdot 1 \pm 7.0$ \\
\hline Cigarette smokers (\%): & & \\
\hline $\begin{array}{l}\text { Current } \\
\text { Ex }\end{array}$ & $\begin{array}{l}44 \cdot 7 \\
18 \cdot 4 \\
36 \cdot 9\end{array}$ & $\begin{array}{l}43 \cdot 2 \\
18 \cdot 9 \\
37.9\end{array}$ \\
\hline Alcohol consumption (drinks/week) & & \\
\hline$($ mean \pm SD) & $7 \cdot 2 \pm 10 \cdot 0$ & $12 \cdot 5 \pm 14 \cdot 6$ \\
\hline $\begin{array}{l}\text { Caffeine consumption (cups tea/ } \\
\text { tea/coffee/day) (mean } \pm \text { SD) }\end{array}$ & $2 \cdot 5 \pm 2 \cdot 8$ & $2.7 \pm 3.2$ \\
\hline $\begin{array}{l}\text { Use of prescribed medication } \\
\text { in previous year }(\%)\end{array}$ & $26 \cdot 3$ & $16 \cdot 2$ \\
\hline $\begin{array}{l}\text { History of fever in } \\
\text { preceding } 3 \text { months (\%) }\end{array}$ & 7.9 & $13 \cdot 5$ \\
\hline $\begin{array}{l}\text { History of urogenital } \\
\text { disorders }(\%)^{*}\end{array}$ & $23 \cdot 7$ & 29.7 \\
\hline $\begin{array}{l}\text { Presence of varicocele (\%) } \\
\text { Other abnormal medical }\end{array}$ & $15 \cdot 8$ & $32.4 \ddagger$ \\
\hline $\begin{array}{l}\text { history }(\%) \dagger \\
\text { Testicular vol (ml): }\end{array}$ & $8 \cdot 1$ & $8 \cdot 1$ \\
\hline $\begin{array}{l}\text { Right (mean } \pm \text { SD) } \\
\text { Left }\end{array}$ & $\begin{array}{l}22 \cdot 1 \pm 4 \cdot 0 \\
21 \cdot 1 \pm 3 \cdot 8\end{array}$ & $\begin{array}{l}21 \cdot 5 \pm 4.7 \ddagger \\
20 \cdot 7 \pm 5.0 \ddagger\end{array}$ \\
\hline $\begin{array}{l}\text { For semen analysis: } \\
\text { Duration of sexual } \\
\text { abstinence (days) } \\
\text { Age of semen sample at } \\
\text { analysis (mins)(mean } \pm \text { SD) }\end{array}$ & $\begin{array}{c}3 \cdot 7 \pm 4 \cdot 9 \\
54 \cdot 2 \pm 32 \cdot 1\end{array}$ & $\begin{array}{c}2 \cdot 8 \pm 2 \cdot 2 \\
55 \cdot 8 \pm 33 \cdot 2\end{array}$ \\
\hline
\end{tabular}

*Urinary tract infection, venereal disease, or testicular trauma. †History of diabetes, hepatitis, rheumatic fever.

$t_{n}=34$.

All differences between exposed and unexposed groups not significant $(p>0.05)$.
Ratcliffe, Schrader, Clapp, Halperin, Turner, Hornung

air levels were comparable in both surveys.

Eight hour TWA breathing zone exposures werd generally similar to those indicated by area samples; with an overall geometric mean of $6.6 \mathrm{ppm}$ but varied by job (table 1). Men who had close contact with the slurry (hand dippers, utility investors, and grabbef operators) had, as expected, higher breathing zonē exposures (ranging from a mean of 5.7 to $14.5 \mathrm{ppm}$ than shell processors and supervisors (ranging from mean of 1.6 to $8.5 \mathrm{ppm}$ ). The recovery of analyte from spiked samples was less than $100 \%$ and as low as $60 \% .^{16}$ The spiking data were not used to correct the actual exposure but measurements suggest that air borne exposures may be higher than indicated by these data.

\section{URINE SAMPLES}

All but two urine samples showed detectable excretion of 2EAA among workers exposed to 2EE (table 2) ranging from 16 to $163 \mathrm{mg} 2 \mathrm{EAA} / \mathrm{g}$ creatinine fo९ individual voids, indicating absorption of $2 \mathrm{EE}$. There were insufficient data statistically to evaluate differences between job categories; however, grabbe operators and shill processors had higher levels of 2EAA excretion (with means 485 and $73 \mathrm{mg} / \mathrm{g}^{\circ}$ creatinine respectively) than hand dippers (mean $3 \theta^{\circ}$ $\mathrm{mg} / \mathrm{g}$ creatinine) in this limited series, despito apparently less opportunity for airborne and skirk exposure. In some cases urine samples were collecteक sequentially from individuals over a workshift, 28 hours, or over several days. There was some evidence that excretion of 2EAA in individuals increased during the workday (data not shown: see ref 16) ands decreased on days off work. It was not possible however, to determine adequately whether 2EAA excretion increased during the workweek due to sampling variability.

\section{CHARACTERISTICS OF THE GROUPS}

There were no statistically significant differenceș between the exposed and unexposed groups for characteristics identified by questionnaire and physical examination (table 3). All the participants were white (except one Hispanic unexposed worker and of similar age (mean 30) and duration of employment. The average duration of employment ins jobs exposed to $2 \mathrm{EE}$ was less than the total employment time for exposed men due to priof periods spent in other, unexposed, job categories by some workers. One exposed subject was found to be severely oligozoospermic; on physical examination the cause was determined to be small testicular size which preceded employment in this occupation. This subject was eliminated from further analysis. Three exposed men declined the physical examination. A higher proportion of exposed men had evidence of $\frac{8}{8}$ 
Table 4 Semen volume, sperm concentration, and count in unexposed and exposed workers

\begin{tabular}{|c|c|c|c|c|c|}
\hline \multirow[b]{2}{*}{ Characteristic } & \multicolumn{2}{|c|}{ Unexposed $(n=38)$} & \multicolumn{2}{|c|}{ Exposed $(n=37)$} & \multirow[b]{2}{*}{$p^{*}$} \\
\hline & Mean & $S D$ & Mean & $S D$ & \\
\hline $\begin{array}{l}\text { Semen pH } \\
\text { Adjusted mean } \ddagger \\
\text { Semen volume (ml) } \\
\text { Adjusted mean§ } \\
\text { Sperm concentration (millions/ml) } \\
\text { Adjusted means } \\
\text { Sperm count (millions/ejaculate) } \\
\text { Adjusted mean } \\
\text { \%Subjects with sperm concentration } \leqslant 20 \text { million } / \mathrm{ml}\end{array}$ & $\begin{array}{r}8.08 \\
8.09 \\
3 \cdot 1 \\
3.0 \\
60.2 \\
53 \cdot 3 \\
178.6 \\
153.9 \\
10.5\end{array}$ & $\begin{array}{r}0 \cdot 18 \\
1 \cdot 4 \\
37 \cdot 0 \\
118 \cdot 0\end{array}$ & $\begin{array}{r}8 \cdot 03 \\
8 \cdot 01 \\
2 \cdot 8 \\
2 \cdot 9 \\
48 \cdot 5 \\
45 \cdot 0 \\
123 \cdot 4 \\
112 \cdot 7 \\
16 \cdot 2\end{array}$ & $\begin{array}{l}30 \cdot 2 \\
81 \cdot 7\end{array}$ & $\begin{array}{l}\text { NS } \\
\text { NS } \\
\text { NS } \\
0.05 \\
\text { NS }\end{array}$ \\
\hline
\end{tabular}

NS $=$ Not significant $(p>0.05$ (two sided)).

* Two sided p value for the effect of exposure adjusted for other factors in the model or + two sided Fisher's exact test.

†Adjusted for abstinence $(p=0.03)$ and presence of varicocele $(p=0.04)$.

$\S$ Adjusted for abstinence $(p=0.02)$ and subject's age $(p=0.04)$.

$\|$ Adjusted for use of prescription medication in past year $(p<0.01)$ and presence of varicocele $(p<0.01)$.

varicocele on physical examination $(32 \% v 16 \%$ in controls), although this difference was not statistically different. The mean testicular volumes of exposed and unexposed subjects were $20 \cdot 7 / 21 \cdot 5$ and $21 \cdot 1 / 22 \cdot 1 \mathrm{ml}$ (left/right) respectively and did not differ significantly between the two groups.

\section{SEMEN ANALYSIS}

The mean semen volume and sperm concentration among the exposed group were lower than among unexposed workers, but the differences were not statistically significant before or after correction for the effect of significant confounders (table 4). The sperm count per ejaculate, however (calculated as sperm concentration (millions/ml) multiplied by semen volume $(\mathrm{ml})$ ), was marginally significantly lower among men exposed to $2 \mathrm{EE}(\mathrm{p}=0.05)$ after consideration of the potentially confounding factors listed in the methods section. Only the rise of prescription medication and the presence of varicocele were significant confounders (table 4). The proportion of men with oligozoospermia (a sperm concentration of $20 \mathrm{million} / \mathrm{ml}$ or less) was higher in the exposed group than in the unexposed group $(16.2 \% v 10.5 \%)$ but this difference was not significant (table 4). There were no azoospermic men. No significant differences between exposed and unexposed men were found with respect to measures of sperm pH (table 4), sperm viability, percentage motility or velocity (table 5 ), the overall proportion of sperm with normal morphology (oval heads and normal tails) (table 6), or morphometry (table 7) after adjustment for significant confounding variables where specified in the tables. (In the case of sperm velocity, morphology, and morphometry none of the independent variables included in the regression models was a significant confounder).

In the case of abnormal sperm forms (table 6) the exposed men had a significantly lower proportion of double headed sperm and a significantly higher proportion of immature forms (NB $p \leqslant 0.001$ was taken as the level of significance for the $\chi^{2}$ test used in the CATMOD procedure to avoid small differences, given the large number of observations ( 200 cells per subject) being detected as statistically significant.

The possibility that duration of exposure due, for example, to a cumulative effect of exposure on

Table 5 Sperm viability, motility, and velocity in unexposed and exposed workers

\begin{tabular}{|c|c|c|c|c|c|}
\hline \multirow[b]{2}{*}{ Characteristics } & \multicolumn{2}{|c|}{ Unexposed $(n=38)$} & \multicolumn{2}{|c|}{ Exposed $(n=36)^{*}$} & \multirow[b]{2}{*}{$p \dagger$} \\
\hline & Mean & $S D$ & Mean & $S D$ & \\
\hline $\begin{array}{l}\text { Viability by stain exclusion (\%) } \\
\text { Adjusted mean } \ddagger \\
\text { Viability by hyposomotic swelling (\%) } \\
\text { Adjusted mean } \S \\
\text { Motility ( } \%) \\
\text { Adjusted mean } \| \\
\text { Velocity (path length) }(\mu \mathrm{m} / \mathrm{sec}) \\
\text { Velocity (distance) }(\mu \mathrm{m} / \mathrm{sec}) \\
\text { Ratio of length/distance velocity }\end{array}$ & $\begin{array}{r}71 \cdot 2 \\
72 \cdot 1 \\
66 \cdot 8 \\
67 \cdot 5 \\
40 \cdot 4 \\
39 \cdot 8 \\
65 \cdot 2 \\
39 \cdot 8 \\
0 \cdot 7\end{array}$ & $\begin{array}{r}9 \cdot 1 \\
10 \cdot 2 \\
12 \cdot 3 \\
14 \cdot 2 \\
8 \cdot 8 \\
0 \cdot 1\end{array}$ & $\begin{array}{r}71 \cdot 5 \\
72 \cdot 3 \\
68 \cdot 6 \\
69 \cdot 4 \\
43 \cdot 9 \\
43 \cdot 6 \\
65 \cdot 6 \\
40 \cdot 2 \\
0 \cdot 7\end{array}$ & $\begin{array}{r}10 \cdot 1 \\
7 \cdot 6 \\
10 \cdot 5 \\
13 \cdot 3 \\
7 \cdot 7 \\
0 \cdot 1\end{array}$ & $\begin{array}{l}\text { NS } \\
\text { NS } \\
\text { NS } \\
\text { NS } \\
\text { NS } \\
\text { NS }\end{array}$ \\
\hline
\end{tabular}

NS $=$ Not significant $(p>0.05$ ( 2 sided $)$ ).

* One sample insufficient for viability, motility, and velocity determination due to low sperm count.

+ Two sided $p$ value for the effect of exposure adjusted for other factors in the model.

$\ddagger$ Adjusted for abstinence $(p=<0.01)$.

$\$$ Adjusted for presence of varicocele $(p=0.01)$.

\|Adjusted for presence of varicocele $(p=0.03)$. 
Table 6 Sperm morphology classifications* in unexposed and exposed workers

\begin{tabular}{|c|c|c|c|c|c|}
\hline \multirow[b]{2}{*}{ Category } & \multicolumn{2}{|c|}{$\begin{array}{l}\text { Unexposed } \\
(n=38)\end{array}$} & \multicolumn{2}{|c|}{$\begin{array}{l}\text { Exposed } \\
(n=37)\end{array}$} & \multirow[b]{2}{*}{$p \dagger$} \\
\hline & Mean & $S D$ & Mean & $S D$ & \\
\hline $\begin{array}{l}\text { Oval (normal) } \\
\text { heads (\%) }\end{array}$ & \multicolumn{2}{|c|}{$79.42 \pm 10.59$} & \multicolumn{2}{|c|}{$78.02 \pm 9.47$} & $\begin{array}{l}\text { NS } \\
p \ddagger\end{array}$ \\
\hline $\begin{array}{l}\text { Macrocephalic (large } \\
\text { heads (\%) }\end{array}$ & \multicolumn{2}{|c|}{$1.40 \pm 2.39$} & \multicolumn{2}{|c|}{$0.95 \pm 0.70$} & NS \\
\hline $\begin{array}{l}\text { Microcep (\%) } \\
\text { headss }(\%) \\
\text { Absent heads (\%) } \\
\text { Tapered heads (\%) } \\
\text { Double heads }(\%) \\
\text { Amorphous heads (\%) } \\
\text { Abnormal tails }(\%) \\
\text { Immature forms (\%) }\end{array}$ & \multicolumn{2}{|c|}{$\begin{array}{l}0.40 \pm 0.56 \\
1.78 \pm 1.46 \\
3.58 \pm 4.24 \\
1.65 \pm 3.16 \\
1.00 \pm 1.92 \\
3.38 \pm 3.15 \\
7.40 \pm 6.22\end{array}$} & \multicolumn{2}{|c|}{$\begin{array}{l}0.36 \pm 0.37 \\
1.97 \pm 1.70 \\
3.65 \pm 3.55 \\
0.95 \pm 1.11 \\
1.18 \pm 1.01 \\
4.05+3.89 \\
8.82 \pm 6.71\end{array}$} & $\begin{array}{l}\text { NS } \\
\text { NS } \\
\text { NS } \\
<0.001 \\
\text { NS } \\
\text { NS } \\
0.001\end{array}$ \\
\hline
\end{tabular}

NS $=$ Not significant $(p>0.05(2$ sided $)$ ).

*Mean \% of two slides: 200 cells read/slide.

tp Value of 2 sided $t$ test (normal forms).

$\pm \mathrm{p}$ Value of $\chi^{2}$ test for simultaneous analysis of ratio of each abnormal form in comparison with normal forms for exposed and unexposed groups (CATMOD procedure). Note that this analysis does not compare the difference between means for each abnormal category as in the $t$ test.

spermatogonial cells or the hypothalamopituitary testicular axis, was examined. Duration of exposure was calculated as the cumulative total of months of potential exposure to $2 \mathrm{EE}$ based on time in different jobs since the start of employment reported by the worker. No effect on the various semen characteristics was observed when a test for linear trend was performed. It should be noted, however, that several currently exposed workers had not had continuous potential exposure to 2EE since the start of employment due to time spent in other departments or away from work. Groups considered to have potentially higher exposure to 2EE through air and skin contact (based on industrial hygiene data and observation of work practices) - that is, hand dippers, grabber operators, and utility investors $(n=10)$-were also compared separately with workers with potentially lower exposure and unexposed men in the regression analyses. No differences in semen characteristics due to potential intensity of current exposure were observed; the number of workers in each exposure

Table 7 Sperm morphometry in unexposed and exposed workers

\begin{tabular}{lrrrrrl}
\hline & \multicolumn{3}{c}{ Unexposed $(n=38)$} & \multicolumn{3}{c}{ Exposed $(n=37)$} \\
\cline { 2 - 3 } Category & Mean & $S D$ & & Mean & $S D$ & $p^{*}$ \\
\hline Area $\left(\mu \mathrm{m}^{2}\right)$ & 9.0 & 1.0 & 9.0 & 0.8 & NS \\
Perimeter $(\mu \mathrm{m})$ & 11.4 & 0.6 & & 11.5 & 0.6 & NS \\
Length $(\mu \mathrm{m})$ & 4.4 & 0.3 & & 4.5 & 0.3 & NS \\
Width $(\mu \mathrm{m})$ & 2.6 & 0.2 & & 2.6 & 0.1 & NS \\
\hline
\end{tabular}

NS $=$ Not significant $\left[p>0.05\left(2\right.\right.$ sided $t$ test or $>0.001\left(\chi^{2}\right.$ test $)$; see text for explanation). ${ }^{*} p$ Value of 2 sided $t$ test.
Ratcliffe, Schrader, Clapp, Halperin, Turner, Hornung group may, however, be too small to detect an effect. (Insufficient numbers of men contributed urine samples to make a comparison with their semen character - . istics valid.)

\section{Discussion}

The data presented here show a statistically significant $\frac{\sqrt{\frac{6}{7}}}{7}$ decrease in the mean sperm count per ejaculate (due principally to a lower sperm concentration ando reflected in the higher proportion of oligozoospermic men in the exposed group) among workers exposed to $2 \mathrm{EE}$ compared with unexposed workers from the same plants. A conservative approach to the statisticalo interpretation of data where multiple tests are compared is to use a Bonferroni correction factor to 3 obtain the acceptable level of significance for each test. ${ }^{30}$ In such a case the effect of exposure to $2 \mathrm{EE}$ onj sperm count could be considered to be of borderline or no significance (depending on whether a one or two sided $p$ value is considered). Nevertheless, the effect of exposure on sperm count is in the direction hypothesised and is consistent with evidence of degeneration of seminiferous tubules from several animal species ${ }^{7-12}$ and of oligozoospermia in rats ${ }^{13}$ exposed to $2 \mathrm{EE}$.

No statistically significant differences in semeno volume, sperm concentration, semen $\mathrm{pH}$, viability motility, velocity, and normal morphology oro testicular volume were observed between exposed ands unexposed men. These results did not change when the potentially confounding effects of sexual abstinence $\frac{\mathrm{D}}{\mathrm{D}}$ sample age, caffeine, alcohol, and tobacco consump 0 tion, urogenital and other medical disorders, and $\vec{\overrightarrow{ }}$ other factors were considered. The two groups differed $\beta$ with respect to the proportion of certain categories of abnormal sperm shapes, exposed men having significantly higher proportion of immature forms ando a lower proportion of double headed forms. In view of 3 the small absolute differences in these proportions ando the lack of consistency of an exposure effect, however we consider that there is insufficient evidence fromo these data to conclude that $2 \mathrm{EE}$ adversely affects sperm morphology in this group, although 2EE haso been shown to affect sperm morphology in rats and mice. ${ }^{1314}$ No effect of duration of exposure to $2 \mathrm{EE}$ one semen quality was observed.

Possibly the sperm concentrations of both groups in this study are adversely affected by occupational or N other factors that could not be studied directly, so that it may not be possible to distinguish a specific effecto due to 2EE alone given the limited sample size and interpersonal variation in this characteristic. Most workers in the control group and some of the groups exposed to 2EE reported exposure to one or other agent, such as metal fumes and dusts, solventso (perchlorethylene for example) or heat and vibration $\sqrt{\mathbb{D}}$ whereas none of these could be quantified, one or aे 
combination of them may also affect semen quality. It is also possible that control subjects may be exposed to 2EE-for example, during occasional visits to the investing departments or through low level contamination of general worksite air-although none of the nine urine samples (from three controls) contained detectable levels of 2EAA. To the extent to which other exposures were reported more frequently by control subjects than by men exposed to 2EE (particularly heat, since the investing rooms tended to be somewhat cooler than certain other areas of the plant), and to which exposure to $2 \mathrm{EE}$ among controls is possible, the results of the study would tend to be biased against finding a significant adverse effect of exposure to 2EE rather than the reverse.

Several other methodological and biological considerations should be taken into account in interpreting these results. Possibly the results of the study may be biased if systematic differences exist between the two groups with respect to participants and nonparticipants-for example, if men with suspected reproductive problems were more likely to participate in the exposed group than the unexposed group or vice versa. The possibility of selection bias is increased when the participation rate is low, particularly in the case of the controls. All potentially exposed men were interviewed in the same manner to solicit participation and volunteers for the comparison group were recruited randomly from the pool of unexposed workers, which minimised the possibility of systematic bias at the sample selection stage. There were no clear differences between participants and non-participants in the exposed group for demographic characteristics for which information was available to the investigators. (Inadequate information on unexposed non-participants was available.) Further, the reasons given for not participating were generally unrelated to factors that may potentially affect semen quality. Whereas selection bias cannot be ruled out, we do not consider it likely that it could explain our results, albeit, with a participation rate of only $50 \%$ for eligible exposed and $26 \%$ for eligible non-exposed, bias must be considered another explanation for the observed results.

The number of subjects studied may limit the ability to detect small changes in certain semen characteristics due to exposure even if underlying differences are present. Our sample of 37 exposed and 38 unexposed men was sufficient to have had an $80 \%$ chance of detecting an approximately $39 \%$ or greater difference in mean sperm concentration compared with the adjusted mean for the unexposed group at a two sided alpha level of 0.05 . For semen volume, our sample size permitted an $80 \%$ chance of detecting a $20 \%$ or greater decrease in volume compared with the unexposed group at alpha $=0.05$. Similarly, for sperm motility and velocity, an approximately $26 \%$ and $10 \%$ difference (respectively) could have been detected; for the proportion of normally shaped sperm, an approximately $15 \%$ difference could be detected in exposed workers. Thus the possibility that smaller true differences in semen characteristics exist between the groups cannot be determined with confidence in this study population.

The question then arises as to whether a possible effect of $2 \mathrm{EE}$ on certain semen characteristics may not have been observable at the time of the study due to recent withdrawal of the use of $2 \mathrm{EE}$ in two of the three buildings. As the data in table 2 indicate, the airborne levels of $2 \mathrm{EE}$ were lower in building $\mathrm{A}$ at the time of the semen study than two months earlier (approximately $3 \mathrm{ppm} v 17 \mathrm{ppm}$ ), and were comparable with those in building $C$, where the use of $2 \mathrm{EE}$ was also suspended. By contrast, air levels in building B, where the use of 2EE had not yet been discontinued, were similar at both sampling dates (about $11 \mathrm{ppm}$ and 15 $\mathrm{ppm}$ respectively). Since, however, this reduction in potential exposure occurred within the average duration of a spermatogenic cycle (of about 70 days), an effect on semen quality would probably still be observable at the time of study, even assuming complete reversibility of a putative effect.

In this population the presence of a varicocele was associated with a decrease in semen volume, concentration, count, viability, and motility. This finding is supported by data from fertility clinic studies, ${ }^{31}$ although not all authors have found such an association. ${ }^{32}{ }^{33}$ The taking of prescribed medication in the past year was also associated with a decrease in sperm concentration and count; in this case, qualitative examination of the data indicated that men taking long term medication were more likely to have sperm concentrations below 20 million per $\mathrm{ml}$ than those not taking medication. Clearly, it is not possible to distinguish a putative effect of a drug from a direct effect of the condition under treatment, particularly where no condition or medication in common was reported. We did not find an association of the subjects' age or alcohol use on semen characteristics as in our previous study ${ }^{19}$; this may be due to the smaller range of age and alcohol use in this population. Abstinence was associated with a lower semen volume as found previously by us ${ }^{19}$ and by other authors, ${ }^{34}$ but not, as might be expected, significantly with sperm concentration, even when forced into the regression model. This may be due to the similarity of, or possible errors in, reporting abstinence times in this population.

In conclusion, our findings suggest a possible effect of exposure to $2 \mathrm{EE}$ on sperm counts in these workers at levels considerably lower than the current OSHA PEL of $200 \mathrm{ppm}$ but no significant differences in other parameters of sperm morphology or function. Other factors may possibly be affecting the semen quality of 
both groups or the results may reflect a bias introduced by the low participation rates. Given the toxicological evidence which clearly shows the testicular toxicity of 2EE in several species, the results of this semen study would suggest limiting exposure and that follow up studies, in other populations exposed to $2 \mathrm{EE}$, should be conducted to confirm this interpretation.

We are grateful for the help of $\mathrm{Mr}$ Roy Marvin and $\mathrm{Mr}$ Ronald Maize (company management), James Oser, and Dr Shiro Tanaka (NIOSH) in conducting this study, the computer help of B Walpole, C Battaglia, and Kathy Hicks, and Joyce Godfrey for manuscript preparation.

Requests for reprints to: Dr Steven Schrader, Experimental Toxicology Branch, National Institute for Occupational Safety and Health, 4676 Columbia Parkway, Cincinnati, Ohio 45226, USA.

\section{References}

1 National Institute for Occupational Safety and Health. Current intelligence bulletin no 39. Glycol ethers: 2-methoxyethanol and 2-ethoxyethanol. Cincinnati: NIOSH, 1983. (DHHS (NIOSH) pub no 83-112; 1983.)

2 National Institute for Occupational Safety and Health. National occupational exposure survey 1982-1984. Cincinnati: Surveillance Branch, Division of Surveillance, Hazard Evaluations and Field Studies, NIOSH, 1985.

3 US Department of Labor, Occupational Safety and Health Administration. General industry standards. Washington: US Government Printing Office, 1981. (Pub No 2206, 29 CFR 1910.1000.)

4 TLV Airborne Contaminants Committee. Threshold limit values for chemical substances and physical agents in the workroom environment with intended changes for 1984-1985. Cincinnati: American Conference of Governmental Industrial Hygienists, 1984.

5 Galloway S, Armstrong MA, Reuben C, et al. Chromosome aberration and sister chromatid exchange tests in Chinese hamster ovary cells; evaluations of 108 chemicals. Environ Molec Mutagen 1987;10(suppl 10):1-175.

6 McGregor DB. Genotoxicity of glycol ethers. Environ Health Perspect 1984;57:97-103.

7 Morris HJ, Nelson AA, Calvery HO. Observations on the chronic toxicities of propylene glycol, ethylene glycol, diethylene glycol, ethylene glycol monoethylether and diethylene glycol monoethyl ether. J Pharmacol Exp Ther 1942;74:266-73.

8 Stenger EG, Aeppli L, Muller D, Peheim E, Thomann P. The toxicity of ethylene glycol monoethylether. Arzneimittelforschung 1971;21:880-5.

9 Foster PMD, Creasy DM, Foster JR, Thomas LV, Cook MW, Gangolli SD. Testicular toxicity of ethylene glycol monomethyl and monoethyl ethers in the rat. Toxicol Appl Pharmacol 1983;69:385-99.

10 Cheever KL, Weigel WW, Richards DE, Lal JB, Plotnick HB. Testicular effects of bis (2-methoxyethyl) ethers in the adult rat: equimolar dose comparison with 2-methoxyethyl and 2-ethoxyethanol. Toxicology and Industrial Health (in press).

11 Nagano K, Nakayama E, Koyano M, Oobayaski H, Adachi H, Yamada T. Mouse testicular atrophy inducted by ethylene glycol monoalkyl ethers. Japanese Journal of Industrial Health 1979;21:29-35.

12 Barbee SJ, Terrill JB, DeSousa DJ, Conway CC. Subchronic
Ratcliffe, Schrader, Clapp, Halperin, Turner, Hornung

inhalation toxicology of ethylene glycol monethyl ether in the rat and rabbit. Environ Health Perspect 1984;57:157-63.

13 Oudiz DJ, Zenick H, Niewenhuis RJ, McGinnis PM. Mal尺 reproductive toxicity and recovery associated with acute: ethoxyethanol exposure in rats. J Toxicol Environ Healt 1984;13:763-75.

14 Lamb JC IV, Gulati DK, Russell VS, Hommel L, Sabharwal PSC Reproductive toxicity of ethylene glycol monoethyl ether tested by continuous breeding of CD-1 mice. Environ Health Perspec 1984;57:85-90.

15 Ratcliffe JM, Clapp DE, Schrader SM et al. Health hazar\& evaluation report HETA 84-415-1688. Cincinnati: NIOSH ڤ 1986.

16 Clapp DE, Smallwood AW, Moseley C, Debord KE. Workplace assessment of exposure to 2-ethoxyethanol. Journal of Applied Industrial Hygiene, 1987;2:183-7.

17 National Institute for Occupational Safety and Health. NIOSIR method 1403: 2 ethoxyethanol. NIOSH manual of analyticad methods. Cincinnati: NIOSH, 1984. (DHSS (NIOSH) pub N@ 84-100; 1984.)

18 Smallwood AW, DeBord KE, Lowry LK. Analyses or ethyleneత glycol monoalkyl ethers and their proposed metabolites in? blood and urine. Environ Health Perspect 1984;57:249-53.

19 Ratcliffe JM, Schrader SM, Steenland K, Clapp DE, Turner Tழ̣ Hornung RW. Semen quality in papaya workers with long tern? exposure to ethylene dibromide. Br J Ind Med 1987;44:317-26.

20 Schrader SM, Ratcliffe JM, Turner TW, Hornung RW. The use of new field methods of semen analysis in the study of occupationat hazards to reproduction: the example of ethylene dibromide. $\gamma_{D}$ Occup Med 1987;29:963-6.

21 Eliasson R, Treichl L. Supravital staining of human spermatozoa $\overrightarrow{0}$ Fertil Steril 1971;22:134-7.

22 Jeyendran RS, Van den Ven HH, Perez-Pelaez M, Crabo BG: Zaneveld LJD. Development of an assay to assess the functionab integrity of the human sperm membrane and its relationship to other semen characteristics. J Reprod Fertil 1984;70:219-28.

23 Albertson P, Chang TSK, Vindivich D. Optimal parameters foß̄ the quantitative assessment of sperm motility. J Andro 1984;5:22.

24 Overstreet JW, Katz DF, Hanson FW, Fonseca JR. A simple inexpensive method for objective assessment of human spernf movement characteristics. Fertil Steril 1979;35:54-7.

25 Jenks JP, Cosentino MJ, Cockett ATK. Evaluating spern motility: a comparison of the Rochester motility scoring systen versus videomicrography. Fertil Steril 1982;38:756-9.

26 Zanefield LJD, Polakoski KL. Collection and physical examina@ tion of the ejaculate. In: Hafez ESE, ed. Techniques of human andrology. Amsterdam: Elsevier, 1977;147-72.

27 Schrader SM, Turner TW, Hardin BD, Niemeier RW, Burg JR? Ratcliffe JM. Morphometric analysis of human spermatozoa (abstract). J Androl 1984;5:22P.

28 Statistical Analysis Systems Inc. User's Guide. North Carolina? SAS Institute, 1982

29 Statistical Analysis Systems, Inc. User's Guide. Version 5. North Carolina; SAS Institute, 1985.

30 Neter J, Wasserman W. Applied linear statistical models. Home wood, Illinois; Irwin Inc, 1974.

31 Rodriguez-Rigau LJ, Smith KD, Steinberger E. Relationship of varicocele to sperm output and fertility of male partners in infertile couples. J Urol 1978;120:691-4.

32 Handelsman DJ, Conway AJ, Boylan LM, Turtle JR. Testicula function in potential sperm donors: normal ranges and the effects of smoking and varicocele. Int J Androl 1984;7:369-82

33 Fariss BL, Fenner DK, Plymate SR, Brannen GE, Jacob WHE Thomason AM. Seminal characteristics in the presence of varicocele as compared with those of expectant fathers and prevasectomy men. Fertil Steril 1979;35:325-7.

34 Schwartz D, Laplanche A, Jouannet P, David P. Within-subjeco variability of human semen in regard to sperm count, volumeథ total number of spermatozoa and length of abstinence. $J$ Repro\& Fertil 1979;57:391-5. 